\title{
Ancylostoma (Ancylostoma) buckleyi (Nematoda: Ancylostomatidae): new wild host and distribution expansion
}

\author{
Ancylostoma (Ancylostoma) buckleyi (Nematoda: Ancylostomatidae): novo hospedeiro \\ selvagem e expansão de distribuição \\ Nathalia Paula Scioscia ${ }^{1,2 *}$; Pablo Martín Beldomenico ${ }^{2,3}$; Guillermo María Denegri ${ }^{1,2}$

\begin{abstract}
${ }^{1}$ Laboratorio de Zoonosis Parasitarias, Departamento de Biología, Facultad de Ciencias Exactas y Naturales, Universidad Nacional de Mar del Plata - UNMdP, Mar del Plata, Buenos Aires, Argentina

${ }^{2}$ Consejo Nacional de Investigaciones Científicas y Técnicas - CONICET, Ciudad Autónoma de Buenos Aires, Argentina

${ }^{3}$ Laboratorio de Ecología de Enfermedades, Instituto de Ciencias Veterinarias del Litoral, Universidad Nacional del Litoral - UNL, Esperanza, Santa Fe, Argentina
\end{abstract}

Received July 13, 2015

Accepted October 5, 2015

\begin{abstract}
Here we report the occurrence of Ancylostoma (Ancylostoma) buckleyi (Le Roux and Biocca, 1957) (Nematoda: Ancylostomatidae) in the small intestine of Pampas foxes (Lycalopex gymnocercus) (Mammalia: Canidae). This fox is the most abundant native carnivore in southern South America, where it inhabits grasslands, open woodlands and areas highly modified by extensive ranching and agricultural activities. Material from 80 foxes in rural areas of southern Buenos Aires province, Argentina was examined. The intestinal tracts were carefully removed from each carcass and subsequently isolated by ligatures (pylorus and rectum). Examination of the intestinal content was performed using the sedimentation and counting technique. Four foxes (5\%) were found to be parasitized with adult specimens of $A$. buckleyi. This is the first report of Ancylostoma (A.) buckleyi in Argentina and adds L. gymnocercus as new host of this nematode species.
\end{abstract}

Keywords: Lycalopex gymnocercus, Pampas fox, Ancylostoma buckleyi, Argentina, South America.

\section{Resumo}

O presente estudo relata a ocorrência de Ancylostoma (Ancylostoma) buckleyi (Le Roux and Biocca, 1957) (Nematoda: Ancylostomatidae) no intestino delgado do Graxaim do campo (Lycalopex gymnocercus) (Mammalia: Canidae). Essa raposa é o carnívoro nativo mais abundante no sul da América do Sul, onde habita nas pastagens, florestas abertas e áreas altamente modificadas pelas atividades pecuária extensiva e agrícola. Material de 80 raposas, em áreas rurais do sul da província de Buenos Aires, Argentina, foi examinado. Os tratos intestinais foram cuidadosamente removidos de cada carcaça e, posteriormente, isolados por ligaduras (piloro e reto). O exame do conteúdo intestinal foi realizado, utilizandose a técnica de sedimentação e contagem. Quatro raposas (5\%) foram encontradas parasitadas com espécimes adultos de A. buckleyi. O estudo registra, pela primeira vez, a ocorrência de Ancylostoma (A.) buckleyi na Argentina e adiciona L. gymnocercus como novo hospedeiro dessa espécie de nematoides.

Palavras-chave: Lycalopex gymnocercus, Graxaim do campo, Ancylostoma buckleyi, Argentina, América do Sul.

\section{Introduction}

Hookworms of the genus Ancylostoma occur in a wide range of vertebrate hosts, although only carnivores seem to harbor a significant number of species (THATCHER, 1971; LICHTENFELS, 2009). Infection with these nematodes in dogs and cats can result in serious disease and even death (BOWMAN et al., 2010). Furthermore, most of the species of hookworms which infect dogs and cats may cause

*Corresponding author: Nathalia Paula Scioscia. Laboratorio de Zoonosis Parasitarias, Departamento de Biología, Facultad de Ciencias Exactas y Naturales, Universidad Nacional de Mar del Plata - UNMdP, Funes 3350, Nivel Cero, 7600, Mar del Plata, Buenos Aires, Argentina. e-mail: nathyvet@hotmail.com zoonotic disease, most notably, cutaneous larva migrans (PROCIV, 1998; BOWMAN et al., 2010). The common hookworms of dogs are Ancylostoma caninum, A. braziliense, A. ceylanicum and Uncinaria stenocephala; and of cats are Ancylostoma tubaeforme, A. braziliense, A. ceylanicum and U. stenocephala (PROCIV, 1998). Other species of as yet unassessed infectivity for humans occur in wild carnivores (THATCHER, 1971).

A. buckleyi was described by Le Roux \& Biocca (1957) on the basis of a few specimens obtained from a puma (Puma concolor) that was kept at London Zoo. The host was believed to have originated 
from Argentina. Some years later, Thatcher (1971) found this species of nematode in Amazonian short-eared fox (Atelocynus microtis) from Colombia. Setasuban (1976) reported the presence of this hookworm in dogs from Australia. Later on, Padilha \& Duarte (1980) described this species in foxes (unspecified species) from Brazil. Later reports of $A$. buckleyi correspond to crab eating foxes, Cerdocyon thous, from Brazil (SANTOS et al., 2003; DUARTE 2007; GRIESE 2007; LIMA et al., 2013).

In Argentina, several species of genus Ancylostoma have been reported in different wild mammals: A. tubaeforme Zeder, 1800 (BELDOMENICO et al., 2005), A pluridentatum Alessandrini, 1905 (MORIENA, 1983), A. caninum Ercolini, 1859 (MARTÍNEZ, 1986, 1987) and undetermined Ancylostoma spp. (ZANINI et al., 2006; MUSSART et al., 2003). However, A. buckleyi has not been described in the country.

The Pampas fox, Lycalopex gymnocercus Fisher, 1914, is the most abundant of the wild canids from South America. This fox inhabits grasslands and open woodlands and it also occurs in areas highly modified by extensive ranching and agricultural activities (LUCHERINI et al., 2008). It is an omnivorous predator showing an opportunistic behavior, as dietary items vary according to seasonal availability and geographic location (FARIAS \& KITTLEIN, 2008).

Here we report the first finding of Ancylostoma (A.) buckleyi in Argentina and add L. gymnocercus as new host of this nematode species, providing a prevalence estimate for rural areas of southern Buenos Aires province, Argentina.

\section{Materials and Methods}

\section{Study area}

The study was conducted in rural areas located in seven departments of southern Buenos Aires province, Argentina, encompassing the ecoregions El Espinal (southwest - El Caldén subregion) and La Pampa (southcentral and southeast) (BURKART et al., 1999). El Caldén subregion of El Espinal is semi-arid, whereas the sampled area of the Pampa eco-region has a humid semi-humid climate. Currently, the study area is dominated by cattle farming and agricultural activities and it is home to high densities of Pampas foxes.

\section{Source of samples}

We used 80 complete intestine samples from road killed L. gymnocercus and dead animals provided by licensed hunters during during 2010 and 2013. Sample collection and transport was permitted by the Ministerio de Asuntos Agrarios and Dirección de Flora y Fauna of Buenos Aires Province.

\section{Parasitological procedures}

The intestinal tracts were carefully removed from each carcass and subsequently isolated by ligatures (pylorus and rectum). Each sample was individually packed and labeled with relevant information. All samples were kept at $-20{ }^{\circ} \mathrm{C}$ prior to processing.
Examination of the intestinal content was performed using the sedimentation and counting technique described by Eckert et al. (2001) with modifications described by Scioscia et al. (2013). Obtained sediments were examined in small portions of $5-10 \mathrm{ml}$ round petri dishes with magnifier lens at $65 x$.

The nematodes collected were washed in saline solution and conserved in formol 4\%, until morphological examination. The worms were cleared in lactophenol, examined microscopically and identified following Lichtenfels (2009), Le Roux \& Biocca (1957) and Thatcher (1971). The identification of specimens recovered was based on the morphological characteristics of three males and three females. The morphometric data were expressed in millimeters unless noted otherwise.

\section{Results and Discussion}

A total of 80 Pampas foxes (36 females and 44 males) were necropsied. The foxes belonged to different departments of the province of Buenos Aires, corresponding 29 to the Pampa eco-region and 51 to the Espinal. All foxes were classified as adults according to their size.

On the basis of morphological examination, the specimens found in the small intestines of foxes were identified as Ancylostoma (Ancylostoma) buckleyi (LE ROUX \& BIOCCA, 1957). As for these morphological characteristics, the buccal capsule was funnel shaped. There were three pairs of ventral teeth and two pairs of dorso-lateral teeth. Anterior part inclined dorsally. Buccal capsule with two triangular lancet inside ventrals. Other characteristics observed for these nematodes were in male $(n=3)$ : total body length $7.38 \mathrm{~mm}$ (range, 6.40-9.12) $(\mathrm{n}=3)$; width $0.49 \mathrm{~mm}(0.45-0.52)$ $(\mathrm{n}=2)$. Total lenght of the oesophagus $1 \mathrm{~mm}(0.87-1.17)(\mathrm{n}=3)$. The spicules were simple and equal, of $0.70 \mathrm{~mm}(0.50-0.80)$ $(n=3)$; gubernaculum was present $(0.03 \times 0.21)(n=3)$. The bursa was well developed; the ratio between posterolateral-mediolateral to mediolateral-externolateral was $1: 1$. The inner branches of the dorsal rays were partially fused (Figure 1; A-E). In the females $(\mathrm{n}=3)$ : total body length $12.12 \mathrm{~mm}$ (range, 9.87-14.87) $(\mathrm{n}=3)$; width $0.52 \mathrm{~mm}(0.50-0.57)(\mathrm{n}=3)$. Total lenght of the oesophagus $1.22 \mathrm{~mm}(1.18-1.25)(\mathrm{n}=3)$. Vulva located in the posterior third of the body. Conically shaped tail $0.16 \mathrm{~mm}(0.13-0.17)(\mathrm{n}=3)$, with a spine at the tip of it $0.02 \mathrm{~mm}(0.02-0.02)(\mathrm{n}=3)$. Eggs in utero: $60.49(52.6-71.01) \times 38.13 \mu \mathrm{m}(34.19-42.08)(\mathrm{n}=8)$ (Figure 1; $\mathrm{F}-\mathrm{H})$.

According to Thatcher (1971), this species has three pairs of ventro-lateral teeth, similar to $A$. caninum, but it also has two pairs of dorso-lateral teeth which are not found in the Ancylostoma species so far described. The terminal portion of the dorsal lobe of the male bursa is also distinctive in $A$. buckleyi. Each side of the terminal fork is tridigitate, as is characteristic of the genus, but the inner two branches are fused near their tips, as is characteristic of $A$. buckleyi. The recorded measurements on specimens found in this study are similar to the descriptions of Le Roux \& Biocca (1957) and Thatcher (1971).

Fourteen adult nematodes of $A$. buckleyi were collected, 11 females and 3 males; all from the Espinal ecoregion. They were in the small intestines of 4 foxes (overall prevalence $=5 \% ; 2$ males and 

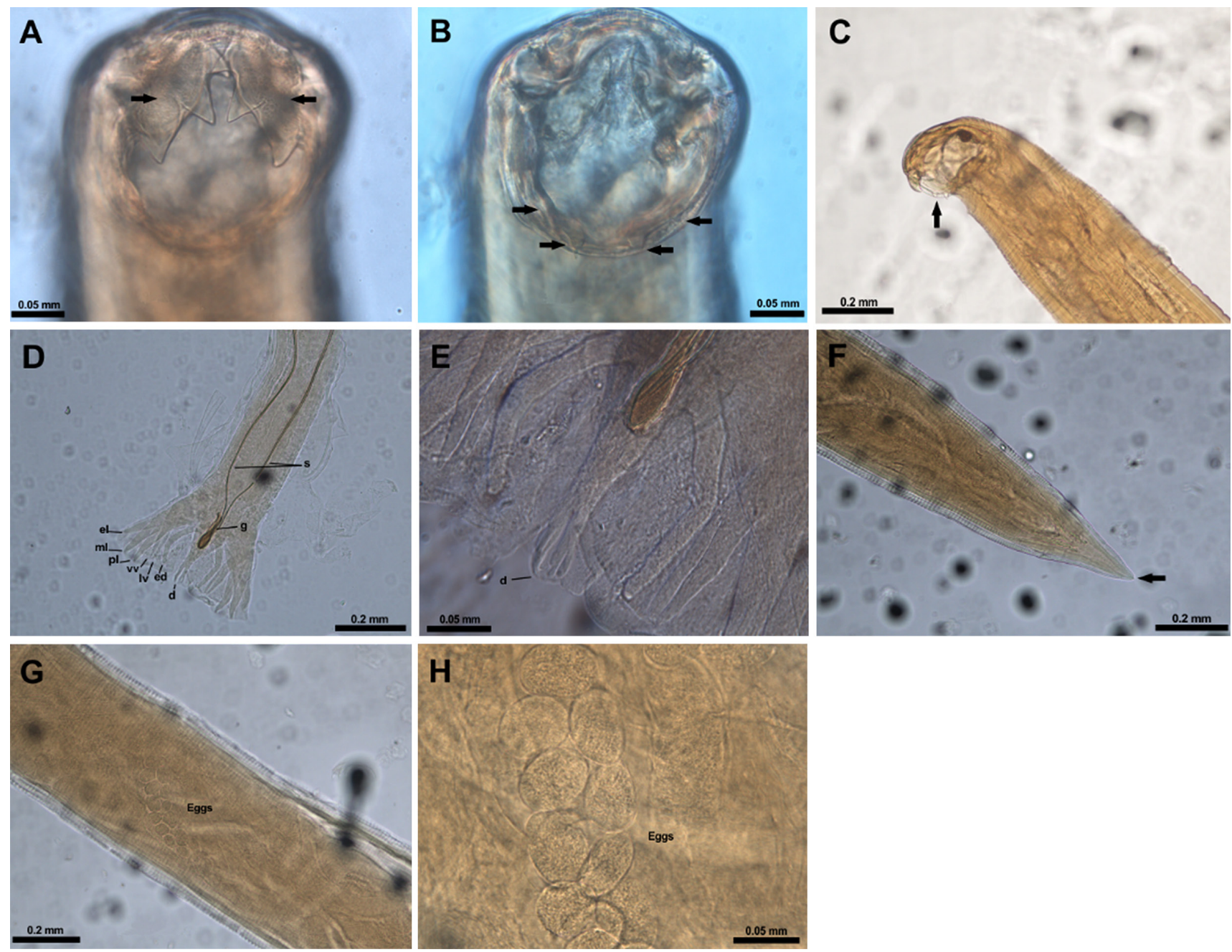

Figure 1. Adults of Ancylostoma (Ancylostoma) buckleyi. Male (A-E). (A) Buccal capsule in dorsal view, the arrows point three pairs of ventral teeth. (B) Buccal capsule in dorsal view, the arrows point two pairs of dorso-lateral teeth. (C) Anterior body end in lateral view, the arrows point a pair of dorso-lateral teeth. (D) Posterior body end in ventral view, showing the spicules (s), gubernaculum (g), and the bursa well developed, with the dorsal ray (d), externodorsal rays (ed), vetrovetral rays (vv), laterovetral rays (lv), externolateral rays (el), mediolateral rays $(\mathrm{ml})$ and posterolateral rays $(\mathrm{pl})$. (E) Posterior body end in ventral view, showing dorsal rays, as each side of the terminal fork is tridigitate and the inner two branches are fused to near their tips. Female (F-H). (F) Posterior body end, the arrow point a spine at the tip of the tail. (G) Posterior body end, showing the eggs in utero. $(\mathrm{H})$ Eggs in utero at a higher magnification.

2 females) ranging in number from 1 to 9 . The medium intensity was 3.5 and the mean abundance 0.18 . Prevalence estimates in the Espinal and La Pampa eco-regions were $8 \%$ and $0 \%$ respectively.

The geographical distribution of hookworm species is imperfectly known because ranges overlap, hosts can harbor several species simultaneously, and only the larger $U$. stenocephala egg can be morphometrically distinguished (EHRENFORD, 1953). To date, A. buckleyi had only been found in carnivores from Colombia and Brazil (THATCHER, 1971; PADILHA \& DUARTE, 1980, SANTOS et al., 2003; DUARTE, 2007; GRIESE, 2007; LIMA et al., 2013).

Pampas foxes is the third naturally infected host species for A. buckleyi, previously found in other two fox species, A. microtis and C. thous (THATCHER, 1971; PADILHA \& DUARTE, 1980, SANTOS et al., 2003; DUARTE, 2007; GRIESE, 2007; LIMA et al., 2013). The original infection in the puma from
Argentina was found in a zoo animal (LE ROUX \& BIOCCA, 1957). For this reason, it seems likely that the foxes are the natural hosts for this parasite. This study represents the first report of natural infection in a host from Argentina and confirms the presence of this nematode species in this country.

The prevalences in C. thous reported by Griese (2007), Duarte (2007) and Lima et al. (2013) were much higher than our estimate in Pampas fox. Lima et al. (2013), suggested that the high prevalences found were due to the enviromental conditions of the region studied (semiarid), which entails that animals concentrate around water bodies, favoring contact and enhancing transmission. This could explain the occurrence of this species only in the Espinal eco-region, because there are fewer water bodies compared with the Pampa (BURKART et al., 1999).

So far no human infection by $A$. buckleyi has been reported, but this cannot be excluded, as other hookworms species are 
often implicated in dermatological lesions, or associated with eosinophilic enteritis. Other manifestations caused by other Ancylostoma in humans include eosinophilic pneumonitis, localized myositis, folliculitis, erythema multiforme, or ophthalmological manifestations (BOWMAN et al., 2010).

Lycalopex gymnocercus may be a source of infection by $A$. buckleyi for domestic dogs and wild carnivores in the province of Buenos Aires, and elsewhere in its distribution.

\section{Acknowledgements}

The authors wish to thank the Municipal Zoonosis Center from General Pueyrredón for providing the space to develop our lab activities. C. Albani PhD for collaboration in the figure design. People of Parasitologic Lab of UNMdP for providing the microscope to photograph nematodes. This work was supported by grants PIP N0029/11 (Consejo Nacional de Investigaciones Científicas y Técnicas, Argentina) and EXA 668/14 (Universidad Nacional de Mar del Plata, Argentina).

\section{References}

Beldomenico PM, Kinsella JM, Uhart MM, Gutierrez GL, Pereira J, Ferreyra H, et al. Helminths of Geoffroy's cat, Oncifelis geoffroyi (Carnivora, Felidae) from the Monte desert, central Argentina. Acta Parasitol 2005; 50(3): 263-266.

Bowman DD, Montgomery SP, Zajac AM, Eberhard ML, Kazacos KR. Hookworms of dogs and cats as agents of cutaneous larva migrans. Trends Parasitol 2010; 26(4): 162-167. http://dx.doi.org/10.1016/j. pt.2010.01.005. PMid:20189454.

Burkart R, Bárbaro NO, Sánchez RO, Gómez DA. Ecorregiones de la Argentina. Buenos Aires: Administración de Parques Nacionales; 1999.

Duarte FH. Helmintofauna em Cerdocyon thous Linnaeus, 1766 (Carnivora, Canidae) na região de Juiz de Fora, Minas Gerais [Dissertation]. Juiz de Fora: Universidade Federal de Juiz de Fora; 2007.

Eckert J, Gemmell MA, Meslin FX, Pawlowski ZS. WHO/OIE manual on echinococcosis in humans and animals: a public health problem of global concern. Paris: World Organization for Animal Health; 2001.

Ehrenford FA. Differentiation of the ova of Ancylostoma caninum and Uncinaria stenocephala infections. Am J Vet Res 1953; 14(53): 578-580. PMid:13092396.

Farias AA, Kittlein MJ. Small-scale spatial variability in the diet of pampas foxes (Pseudalopex gymnocercus) and human-induced changes in prey base. Ecol Res 2008; 23(3): 543-550. http://dx.doi.org/10.1007/ s11284-007-0407-7.

Griese J. Helmintofauna de vertebrados atropelados em rodovias da regiāo de Botucatu, São Paulo [Dissertation]. Botucatu: Universidade Estadual Paulista; 2007.
Le Roux P, Biocca E. Sur una nuova specie del genere Uncinaria e su due specie del genere Ancylostoma. Rend Accad Naz Lincei 1957; 22(2): 192-199.

Lichtenfels JR. Strongylida. In: Anderson RC, Chabaud AG, Willmott $S$, editors. Keys to the nematode parasites of vertebrates: archival volume. Oxfordshire: CABI; 2009. p. 44-68.

Lima RC, Hoppe EGL, Tebaldi JH, Cruz BC, Gomes AAB, Nascimento AA. Gastrintestinal helminths Of Cerdocyon thous (Linnaeus, 1766-Smith, 1839) from the caatinga area of the Paraíba State, Brazil. Semina: Cienc Agrar 2013; 34(6): 2879-2888.

Lucherini M, Pessino M, Farias A. Pampas fox. In: Sillero-Zubiri C, Hoffmann M, Macdonald DW, editors. Canids: foxes, wolves, jackals and dogs: status survey and conservation action plan. Gland: IUCN/SSC Canid Specialist Group; 2008. p. 63-68.

Martínez FA. Helmintofauna de los mamiferos silvestres. Trematodes. Vet Argent 1986; 3(26): 544-548.

Martínez FA. Zooparásitos de mamiferos silvestres. Vet Argent 1987; 4(33): 266-271.

Moriena RA. Cita para la Argentina de Ancylostoma pluridentatum Alessandrini, 1905 (Nematoda, Ancylostomidae) en Felis concolor. Rev Med Vet 1983; 64(3): 184-188.

Mussart NB, Solís GA, Arzuaga SM, Coppo JA. Determinaciones hematológicas y urinarias en aguará-guazú (Chrysocyon brachyurus) en cautiverio en el nordeste argentino. Rev Vet 2003; 14(2): 79-84.

Padilha TN, Duarte MJF. Ancylostoma buckleyi Le Roux \& Biocca, 1957 no estado de Pernambuco, Brasil. Atas Soc Biol Rio de Janeiro. 1980; 21: 3-4.

Prociv P. Zoonotic hookworm infections (Ancylostomosis). In: Palmer SR, Soulsby L, Simpson DIH. Zoonoses. Oxford: Oxford Medical Publications; 1998. p. 803-822.

Santos KR, Catenacci LS, Pestelli MM, Takahira RK, Lopes RS, Da Silva RJ. First Report of Ancylostoma buckleyi Le Roux \& Biocca, 1957 (Nematoda: Ancylostomatidae) infecting Cerdocyon thous Linnaeus, 1766 (Mammalia: Canidae) From Brazil. Rev Bras Parasitol Vet 2003 12(4): 179-181.

Scioscia NP, Beldomenico PM, Petrigh RS, Pierangeli N, Denegri GM. Epidemiological studies on Echinococcus in Pampas fox (Lycalopex gymnocercus) and European hare (Lepus europaeus) in Buenos Aires province, Argentina. Parasitol Res 2013; 112(10): 3607-3613. http:// dx.doi.org/10.1007/s00436-013-3548-3. PMid:23892482.

Setasuban P. Morphology of Ancylostoma buckleyi Le Roux \& Biocca, 1957 in dogs from Cairns, North Queensland, Australia. Southeast Asian J Trop Med Public Health 1976; 7(1): 45-49. PMid:1027107.

Thatcher VE. Some hookworms of the genus Ancylostoma from Colombia and Panama. P Helm Soc Wash 1971; 38(1): 109-116.

Zanini F, Laferrara M, Bitsch M, Pérez H, Elissondo ME. Epidemiological studies on intestinal helminth parasites of the patagonian grey fox (Pseudalopex griseus) in Tierra del Fuego, Patagonia Argentina. Vet Parasitol 2006; 136(3-4): 329-334. http://dx.doi.org/10.1016/j.vetpar.2005.11.014. PMid:16414190. 